\title{
A systematic review of molecular diagnostic methods for the detection of arboviruses in clinical specimens in Brazil and the importance of a differential diagnosis
}

\author{
Marcos Lázaro Moreli* and Vivaldo Gomes da Costa \\ ${ }^{*}$ Correspondence: mlmoreli@hotmail.com \\ Department of Biomedicine, Federal University of Goiás, Jataí, Brazil.
}

\begin{abstract}
Arboviruses (Arthropod-borne viruses) compose a large group of zoonotic viruses that have complex cycles and often cause diseases in humans. This study was aimed at performing a systematic review of molecular diagnostic methods for the detection of arboviruses in clinical samples from Brazil to emphasize the importance of a differential diagnosis. Articles on arbovirus diagnostic methods were searched in databases using descriptors and selection criteria. A total of 19 articles were found that described techniques that may be used for the differential diagnosis of arboviruses. RT-PCR, nested RT-PCR and real-time RT-PCR were the main methods. The samples were collected from the Brazilian Amazon and the state of São Paulo for the diagnosis of dengue, Oropouche fever, yellow fever, Saint Louis encephalitis and Mayaro virus disease. Classical diagnostic methods were rarely used. In addition, molecular methods are not yet fully standardized because several methods did not detect arboviruses. Furthermore, a diagnosis that is based only on clinical and epidemiological data would be premature. Therefore, new entomological research and new differential molecular methods should be performed for the possible isolation of these unknown viruses to contribute to the diagnosis of arboviruses. Thus, additional research should be conducted because these diseases are emerging and reemerging in several countries.
\end{abstract}

Keywords: Arbovirus, systematic review, differential diagnosis, RT-PCR, arboviruses in Brazil

\section{Introduction}

Arboviruses (Arthropod-borne viruses) compose a large group of zoonotic viruses that infect hematophagous arthropods and have complex cycles. Arboviruses are commonly transmitted to humans mainly by the bite of mosquitoes and less frequently by ticks, which results in disease. Arboviruses are classified into the Togaviridae (genus Alphavirus), Flaviviridae (genus Flavivirus), Bunyaviridae (genus Orthobunyavirus and Phlebovirus) and Reoviridae families. Most arboviruses have a single-strand RNA genome with spherical morphology and a diameter that ranges from 45-120 nm [1,2]. The dengue virus (DENV), yellow fever virus (YFV), Japanese encephalitis virus (JEV), Saint Louis encephalitis virus (SLEV), Venezuelan equine encephalitis virus (VEEV), Eastern and Western equine encephalitis viruses, West Nile virus (WNV) and Oropouche virus (OROV) are included in this group of viruses. Arboviruses are clinically important, and at least 2.5 billion people live in areas at risk for dengue [3-5].

Currently, many of the diseases that are caused by arboviruses are considered to be emerging and reemerging. In South America, the DENV, YFV, SLEV, OROV, Mayaro virus (MAYV) and Rocio virus (ROCV) are the main causes of emerging and reemerging diseases. These diseases are an important public health problem, as they cause large epidemics and result in increased financial costs that are associated with diagnosis and treatment. In addition, the mortality rates of several of these diseases are considerable. Despite the worldwide distribution of arboviruses, countries in tropical and subtropical areas with vast forest reserves and diverse fauna represent environments that are more conducive to the ecology of arboviruses. More than $33 \%$ of the territory ( 3 million $\mathrm{km}^{2}$ ) in Brazil consists of natural ecosystems that provide ideal conditions for the development and dissemination of arboviruses $[2,5,6]$.

In Brazil, still were isolated or conducted serological surveys in humans, animals and mosquitoes the following virus shown in (Table 1) [7-17]. In addition, the Chikungunya virus, which originates from Southeast Asia and the East African coast, was isolated; however, all of the cases were imported [18-20]. Most of these infections were asymptomatic. A symptomatic infection is usually accompanied by clinical signs of acute fever, encephalitis and hemorrhagic fever [1,21-24].

The diagnosis of arboviral diseases can be difficult due to the following factors: a clinical similarity to other diseases; the presence of clinically asymptomatic or oligosymptomatic disease; difficult access to reference laboratories that can perform a differential diagnosis; and phylogenetic crossreactions that can occur between serological tests, especially in endemic regions, such as the city of Manaus, Brazil, where dengue can be easily confused with yellow fever (YF), MAYV fever, malaria or Oropouche fever $[\mathbf{2 5}, \mathbf{2 6}]$. In addition to Manaus, concomitant cases of SLEV infection and dengue have occurred in other states, such as São Paulo. Consequently, many of these infections have been neglected, excluding dengue, and few epidemiological studies have been conducted in the country to understand the distribution of these infections. Moreover, 
Moreli et al. Virology Discovery 2013,

http://www.hoajonline.com/journals/pdf/2052-6202-1-1.pdf

doi: $10.7243 / 2052-6202-1-1$

Table 1. Arbovirus isolated in the Brazil.

\begin{tabular}{|c|c|c|c|}
\hline Family & Genus & Virus & Viral Properties \\
\hline Togaviridae & Alphavirus & $\begin{array}{l}\text { Venezuelan/East/West } \\
\text { equine encephalitis } \\
\text { vírus*, Mucambo*, } \\
\text { Trocara, Pixuna*, } \\
\text { Chikungunya } \\
\text { Mayaro*, }^{*} \text { Una*, Aura* }\end{array}$ & $\begin{array}{l}\text { Single-stranded RNA and } \\
\text { the positive sense, size of } \\
9.7-11.8 \mathrm{~kb} \text {, spherical ( } 70 \\
\text { nm diameter), envelope, } \\
3 \text { or } 4 \text { major structural } \\
\text { polypeptides, which } 2 \text { are } \\
\text { glycosylated. Replication: } \\
\text { cytoplasm; Virion matura- } \\
\text { tion: sprouting through the } \\
\text { cell membranes of the host. }\end{array}$ \\
\hline Flaviviridae & Flavivirus & 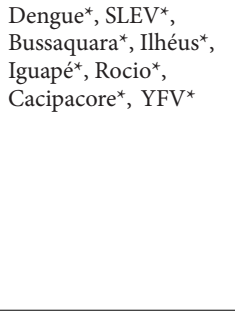 & $\begin{array}{l}\text { Single-stranded RNA and } \\
\text { the positive sense, size of } \\
11-21 \mathrm{~kb} \text {, spherical ( } 45-60 \\
\mathrm{~nm} \\
\text { diameter), envelope, } 3 \\
\text { or } 4 \text { major structural } \\
\text { polypeptides, which } 2 \text { are } \\
\text { glycosylated. Replication: } \\
\text { cytoplasm; Virion } \\
\text { maturation: within the } \\
\text { endoplasmic reticulum. }\end{array}$ \\
\hline Bunyaviridae & $\begin{array}{l}\text { Orthobunyavirus } \\
\text { Phlebovirus }\end{array}$ & 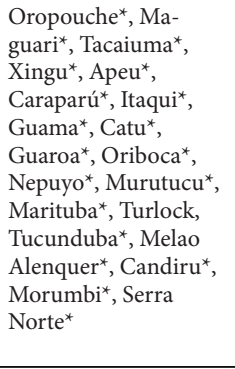 & $\begin{array}{l}\text { Single-stranded RNA with } \\
3 \text { segments, negative sense, } \\
\text { or both senses, size of } \\
11-21 \mathrm{~kb} \text {, spherical ( } 80-120 \\
\text { nm de diameter). Virion } \\
\text { contains one viral RNA de- } \\
\text { pendent RNA polymerase, } \\
4 \text { major } \\
\text { polypeptides and wrap. } \\
\text { Replication: cytoplasm; Vi- } \\
\text { rion maturation: sprouting } \\
\text { in the smooth membranes } \\
\text { of Golgi system. }\end{array}$ \\
\hline
\end{tabular}

${ }^{\star}$ Arboviruses associated with human disease. The more important arboviruses causing human disease are DENV, YFV, OROV, MAYV, SLEV and ROCV [24].

the differential diagnosis of arboviral infections in Brazil has been accomplished in few laboratories and mainly for dengue. In addition, false positives and false negatives can occur, thus "masking" the epidemiological data $[\mathbf{1}, \mathbf{1 1}]$.

An early and accurate diagnosis is critical for successful treatment. The reverse transcriptase-PCR (RT-PCR) method and the variants of this test can meet these requirements because the method is highly sensitive and specific, which allows for the identification of virus in small samples and serotyping to detect the virulence of viral strains $[\mathbf{2 7 , 2 8 ]}$. Few studies have reviewed the criteria, the methods and the application of molecular methods to diagnose the infections that are caused by arboviruses. This study was aimed at performing a systematic review of the scientific literature on the differential molecular diagnostic methods for the detection of arboviruses in clinical samples from Brazil.

\section{Methods}

This study was a systematic review, conducted to identify, analyze and summarize the results of independent studies that were based on the molecular diagnosis of infections that are caused by arboviruses. Commonly, a review of studies can be divided into a narrative, integrative and systematic review in which a statistical test can be applied, called a meta-analysis, which is useful for evaluating treatment studies $[29,30]$. In this study, the researchers developed a research protocol with inclusion and exclusion criteria for the studies that were analyzed and a definition of the outcomes of interest. Therefore, our research strategy was divided into the following phases: (1) the definition of the descriptors, (2) the selection of the data sources, (3) the analysis and data extraction of the articles and (4) the presentation of the results.

\section{Definition of the descriptors-Phase 1}

To meet the objectives of this research, descriptors were defined, which consisted of words or a set of words that represented the subject of the study. The following terms were used in English and in Portuguese for this study: PCR combined with arbovirus/arboviruses; association between the terms molecular diagnostics, differential diagnosis, dengue, SLEV, Venezuelan/East/West equine encephalitis virus, arbovirus in Brazil, YF, West Nile fever, OROV, MAYV, ROCV, Una virus, Bussuquara virus, Pixuna virus, Iguape virus, Ilheus virus, Trocara virus, Cacipacore virus (CPCV), Melão virus, Aura virus and Chikungunya virus.

\section{Selection of data sources-Phase 2}

The following databases were searched: Literatura LatinoAmericana e do Caribe em Ciências da Saúde (LILACS), PubMed, Scientific Electronic Library Online (SciELO) and Google Scholar. All of these databases are indexed by scientific journals. The SciELO includes paper, online newspapers with approximately 290 journals from Brazil, Cuba, Chile and other countries in Latin America, which are provided at no cost. The LILACS database comprises a cooperative network Virtual Health Library (VHL), which includes literature on the health sciences and is published in Latin America and the Caribbean.

These databases were searched from February 2012 to September 2012 using selected keywords, and manuscripts that were published between 1990 and 2012 were evaluated. Reviews and experimental studies that involved animals were excluded from the study.

Analysis and data extraction from the articles-Phase 3 After phases 1 and 2, studies were selected based on the abstract and evaluated independently by two researchers. In this phase, we evaluated the origin, the methodological design and the clarity of the articles.

The researchers met regularly to discuss the studies that were found in the databases (LILACS, SciELO, PubMed and Google Scholar), and this phase of the systematic review consisted of consensus meetings. The following variables were extracted from the studies: the type of the virus that was isolated from clinical specimens; the molecular techniques that were used; the ability of the differential diagnostic methods to accurately diagnose arboviral diseases; the current knowledge of the topic and the possible identification of gaps in knowledge. The data from the articles were carefully analyzed [29-31]. 


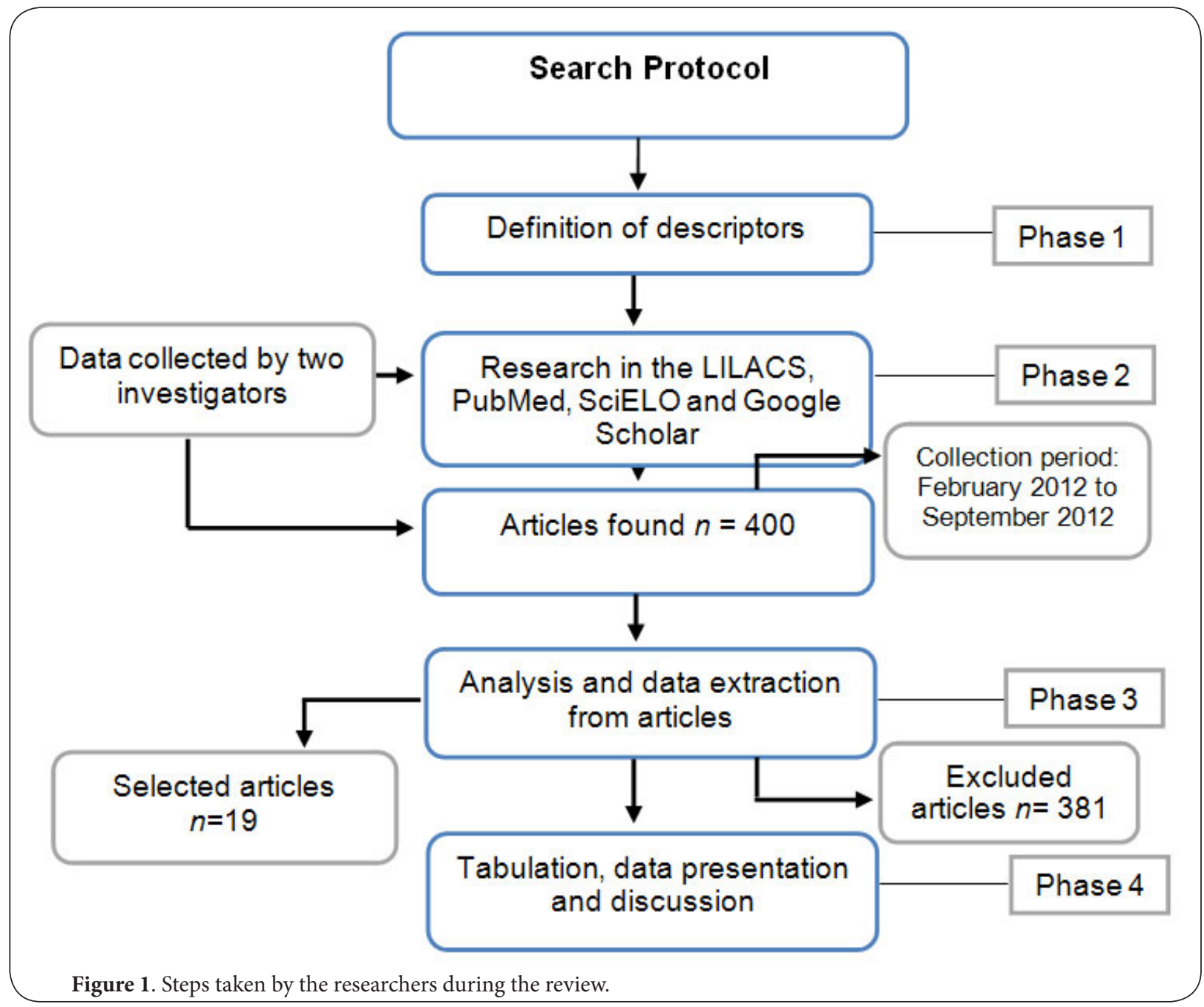

\section{Presentation of the results-Phase 4}

The results of the studies that were included in the final analysis are presented in tables, which highlight the main characteristics of the data. Therefore, a critical summary was prepared by synthesizing the information that was extracted from the articles and by describing the variables that were studied according to the country of origin, year of publication, methodological design, clinical data, parameters and laboratory techniques.

\section{Results}

In this systematic review, articles were selected based on the use of standardized methodology with pre-defined criteria in the studies; this selection criterion was enforced uniformly. Currently, this type of review is preferred in studies because there is a greater risk of bias using other types of review $[29,31]$.

During the completion of phases 1 and 2, a total of 400 articles were accessed from February 2012 to September 2012. After phase 3 , a total of 19 articles were available for the final analysis of the study. The main reasons for the exclusion of articles in phase 3 were a lack of detail in the techniques that were used, that only a serological diagnosis was made and that human samples were not used in the methodology. Phase 4 included the tabulation of the data from these studies. The steps that were followed during the review are outlined in a flow chart (Figure 1).

The studies that used a molecular methodology to detect viruses that were transmitted by arthropods in clinical specimens in Brazil are summarized in (Table 2). The major types of viruses that were evaluated included dengue virus (32\%), OROV (22\%), YFV (11\%), SLEV (11\%), MAYV (11\%), ROCV $(5 \%)$ and CPCV (5\%). Most of the studies were published in 2011 (26\%) and 2012 (16\%). Therefore, these studies were recent, which demonstrates that a major objective of these studies was to determine the distribution of arboviruses in the Brazil using new laboratory methods.

The pioneering studies on arboviruses in Brazil were based on viruses that were isolated from the Brazilian Amazon, where the ecosystem provides conditions that are conducive for the circulation of these viruses [24]. In addition to this 
Moreli et al. Virology Discovery 2013,

http://www.hoajonline.com/journals/pdf/2052-6202-1-1.pdf

doi: $10.7243 / 2052-6202-1-1$

Table 2. Studies in Brazil (1990-2012) that were selected for review and of other countries.

\begin{tabular}{|c|c|c|c|c|c|c|}
\hline Reference & Country & Year of publication & Study design & $n$ sample (human) & Molecular method & Arbovirus \\
\hline$[32]$ & BRAZIL & 2012 & Cohort study & 33 & RT-PCR & $\mathrm{MAYV}^{\dagger}$ \\
\hline [33] & BRAZIL & 2012 & Cohort study & 110 & RT-PCR & $\mathrm{OROV}^{\ddagger}$ \\
\hline [34] & BRAZIL & 2012 & Cohort study & 2 & Nested RT-PCR, Real-time RT-PCR & DENV $^{\varsigma}$ \\
\hline [35] & BRAZIL & 2011 & Cohort study & 71 & Semi-nested RT-PCR, Green qRT-PCR & $\mathrm{YFV}^{*}$ \\
\hline [36] & BRAZIL & 2011 & Case-control & 25 & RT-PCR & YFV \\
\hline [37] & BRAZIL & 2011 & Cohort study & 519 & RT-PCR (duplex, multiplex nested) & SLEV \\
\hline [38] & BRAZIL & 2011 & Cohort study & 94 & RT-PCR & DENV \\
\hline [39] & BRAZIL & 2011 & Case report & 1 & RT-PCR & $\mathrm{CPCV}^{* *}$ \\
\hline [40] & BRAZIL & 2010 & Cohort study & 111 & RT-PCR, RT-PCR multiplex nested & DENV \\
\hline [41] & BRAZIL & 2010 & Short report & 2 & Real-time RT-PCR & DENV \\
\hline [42] & BRAZIL & 2009 & Prospective & 744 & RT-PCR, Real-time RT-PCR & OROV \\
\hline [43] & BRAZIL & 2009 & Cohort study & 16 & Real-time RT-PCR & DENV \\
\hline [44] & BRAZIL & 2008 & Cohort study & 1 & RT-PCR & $\mathrm{ROCV}^{\dagger+}$ \\
\hline [45] & BRAZIL & 2008 & Prospective & 126 & RT-PCR, nested RT-PCR, Real-time RT-PCR & DENV \\
\hline [46] & BRAZIL & 2007 & Cohort study & 3 & RT-PCR & MAYV \\
\hline [47] & BRAZIL & 2007 & Cohort study & 234 & RT-PCR & OROV \\
\hline [48] & BRAZIL & 2005 & Cohort study & 97 & RT-PCR (duplex, multiplex nested) & $A / F^{\ddagger \ddagger}$ \\
\hline [49] & BRAZIL & 2005 & Case report & 1 & RT-PCR & SLEV \\
\hline [50] & BRAZIL & 2002 & Cohort study & 30 & Nested RT-PCR & OROV \\
\hline$[51]$ & FRANCE & 2012 & Cohort study & 69 & qRT-PCR & $\mathrm{CHIKV}^{\S s}$ \\
\hline$[52]$ & $\mathrm{U}^{*}$ & 2012 & Cohort study & 29 & Triplex RT-PCR & 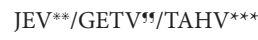 \\
\hline [53] & $\mathrm{U}$ & 2012 & Prospective & - & Multiplex RT-PCR & JEV \\
\hline [54] & IRAN & 2012 & Prospective & 100 & RT-PCR & $\mathrm{CCHFV}^{++\dagger}$ \\
\hline [55] & IRAN & 2012 & Retrospective & 632 & RT-PCR & $\mathrm{WNV}^{\ddagger \ddagger}$ \\
\hline$[56]$ & INDIA & 2012 & Cohort study & 513 & RT-PCR & JEV \\
\hline [57] & $\mathrm{U}$ & 2011 & Prospective & 104 & Real-Time RT-PCR & JEV \\
\hline$[58]$ & $\mathrm{U}$ & 2007 & Prospective & 658 & RT-PCR & CHIKV \\
\hline [59] & French Guiana & 2008 & Retrospective & 222 & RT-PCR & DENV \\
\hline$[60]$ & Malaysia & 2008 & Cohort study & 2.958 & RT-PCR & DENV \\
\hline$[61]$ & Turkey & 2007 & Cohort study & 108 & RT-PCR & CCHFV \\
\hline
\end{tabular}

${ }^{\star}$ Undisclosed; $\uparrow$ Mayaro virus; $\ddagger$ Oropouche virus; $§$ Dengue virus; $*$ Yellow fever virus; 9 Saint Louis Encephalitis virus; ${ }^{* \star C a c i p a c o r e}$

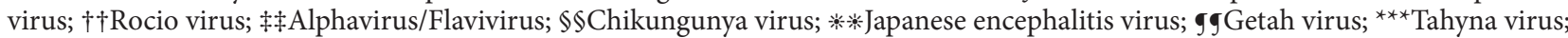
$\dagger \dagger \dagger$ Crimean-Congo hemorrhagic fever virus; $\ddagger \ddagger \ddagger W e s t$ Nile virus.

region, studies were conducted using viruses from the State of São Paulo, which is the most populous state in Brazil and has the largest economy in the country [62]. Additionally, samples were collected from the following cities for virological diagnosis: Oiapoque in the State of Amapá; Recife in the State of Pernambuco; Magalhães Barata, Porto de Moz, Novo Repartimento, Parauapebas, Oriximiná and Maracanã in the State of Pará; Plácido Castro in the State of Acre; Porto Velho and Theobroma in the State of Rondônia; and São Paulo, Ribeirão Preto, São José do Rio Preto, Oswaldo Cruz, Paulo Faria and Flórida Paulista in the State of São Paulo.

When the clinical signs of arbovirus infection were evaluated, the classic triad of acute fever, hemorrhagic fever and encephalitis was observed. In most cases, acute fever occurs; however, this triad can occur simultaneously, which has been observed in patients with a more severe clinical status [63]. The symptoms of the patients who were evaluated in this literature review and the laboratory parameters that were analyzed by three authors $[\mathbf{3 5 , 3 7 , 4 8}]$ are summarized in (Table 3). An overlap of the clinical status for the following infections was observed: dengue, YF, ROCV, OROV, SLEV, MAYV and CPCV. Most of these viruses cause mild symptoms or an acute febrile phase, such as in MAYV and OROV infection. However, viruses, such as dengue [64], YF and SLEV (less frequently), may lead to death.

\section{Discussion}

In the selected studies, most researchers aimed to identify the various serotypes of dengue (DENV1, DENV2, DENV3 and DENV4) because several dengue epidemics have become constant and severe in recent years, thus representing an important public health problem. Therefore, during an epidemic of dengue-3 in the interior of the state of São Paulo, Bernardes-Terzian et al., sought to identify arboviruses in biological samples from 519 individuals with acute febrile illness who were already determined to have dengue based on clinical and epidemiological data. However, when RT-PCR and the variants of this test were performed using primers that were specific for various arboviruses, DENV and SLEV were detected in only $71 \%$ and $1.5 \%$ of the samples, respectively. In $28 \%$ of the samples, arboviruses were not identified [37]. In addition, Santana et al., observed a co-infection between 
Moreli et al. Virology Discovery 2013,

http://www.hoajonline.com/journals/pdf/2052-6202-1-1.pdf

doi: $10.7243 / 2052-6202-1-1$

Table 3. Data related to the symptoms and laboratory parameters of the individuals who were assessed.

\begin{tabular}{|c|c|c|c|c|}
\hline Reference & $\begin{array}{l}\text { Sample collection after the onset of } \\
\text { symptoms }\end{array}$ & Clinical samples collected & Clinical status & Laboratory parameters \\
\hline [32] & $>5$ days & Serum & Fever, headache, arthralgia and myalgia & $\mathrm{NA} \dagger$ \\
\hline [33] & $\mathrm{U}^{*}$ & Cerebrospinal fluid & Meningoencephalitis & NA \\
\hline$[34]$ & $\mathrm{U}$ & Serum & Fever, headache and myalgia & NA \\
\hline$[35]$ & $\mathrm{U}$ & $\begin{array}{l}\text { Serum and } \\
\text { tissue }\end{array}$ & Similar to infection by YFV & $\begin{array}{l}\text { RT-PCR: } S^{\ddagger}=52.1 \% ; \mathrm{Sp}^{\S}=100 \% ; \\
\text { S-N* RT-PCR: } \mathrm{S}=70.9 \% ; \mathrm{Sp}=98.2 \% \text {; } \\
\text { qRT-PCR: } S=92.3 \% ; \mathrm{Sp}=100 \%\end{array}$ \\
\hline [36] & $\mathrm{U}$ & Blood/serum and tissue of humans & Similar to infection by YFV & NA \\
\hline [37] & $\leq 5$ days & Serum & Fever, headache and myalgia & $\begin{array}{l}\text { RT-PCR MN': S=99\%; } \mathrm{Sp}=83 \% \text { to } \\
\text { arbovirus }\end{array}$ \\
\hline [38] & $\leq 5$ and $\geq 3$ days & Blood/serum & Clinical suspicion of dengue & NA \\
\hline [39] & $\mathrm{U}$ & Blood/serum & Suggestive of leptospirosis and YF & NA \\
\hline [40] & $\mathrm{U}$ & Blood/serum & Fever, headache and chills & NA \\
\hline [41] & $\leq 9$ and $\geq 2$ days & Serum, urine and saliva & Fever, headache myalgia and retroocular pain & NA \\
\hline [42] & $\leq 5$ and $\geq 3$ days & Serum & Acute febrile illness & NA \\
\hline [43] & $\mathrm{U}$ & Blood & Compatible with symptoms of dengue & NA \\
\hline [44] & $\geq 5$ days & Autopsied human brain specimen & Encephalitis & NA \\
\hline [45] & $\leq 5$ days & Serum & Fever & NA \\
\hline [46] & $\geq 4$ days & Blood/serum & High fever and arthralgia & NA \\
\hline [47] & $\mathrm{U}$ & Blood/serum & Acute febrile illness & NA \\
\hline [48] & $\leq 5$ days & Blood/serum & Clinical signs suggestive of arboviruses & $\begin{array}{l}\text { RT-PCR D }{ }^{* *}: S c=64 \% ; S p=100 \% \\
\text { RT-PCR MN: } S=99 \% ; S p=83 \%\end{array}$ \\
\hline [49] & $\leq 25$ and $\geq 3$ days & Blood/serum & $\begin{array}{l}\text { Fever, headache, myalgia, eye pain, nausea, } \\
\text { vomiting and rash }\end{array}$ & NA \\
\hline$[50]$ & $\mathrm{U}$ & Serum & $\mathrm{U}$ & NA \\
\hline
\end{tabular}

* undisclosed; †not assessed; $\ddagger$ sensibility; §specificity; 棌semi-nested; gmultiplex nested; ${ }^{* *}$ duplex.

DENV and Plasmodium sp, which is the etiological agent of malaria [40]. Therefore, a differential diagnosis should be concurrently performed for these diseases in endemic areas.

Calzavara-Siva et al., performed an experimental study to develop a diagnostic method that could differentiate between the two clinical forms of dengue (i.e., classical dengue fever and hemorrhagic dengue fever). Therefore, were analyzed the expression levels of six mRNA markers of dengue hemorrhagic fever using real-time RT-PCR. In a patient who was infected with dengue, the markers could identify the evolution of the virus from the classical disease form to the hemorrhagic disease form. Despite the small sample $(n=16)$, these markers may be useful for the prognosis of the severe form of dengue and in a rapid assay with potential clinical use [43]. Moreover, among the studies that were included in this review, only Dos Santos et al., used the ELISA to capture the NS1 antigen in the acute phase of dengue [45]. This method is more sensitive than traditional RT-PCR and is used in many laboratories for the early diagnosis of dengue [65].

In other research has been investigated Oropouche fever in epidemic areas in the Brazilian Amazon. In the study by Vasconcelos et al., $64 \%$ of the samples were positive for the OROV, whereas the prevalence of the OROV among the different regions ranged from $12.7 \%-52.1 \%$ in the study by Azevedo et al., [42,47]. Bastos et al., evaluated cerebrospinal fluid samples from patients with meningoencephalitis in the state of Amazonas and detected the presence of the OROV in approximately $3 \%$ of the samples. This study demonstrated that this disease, although rare, could be investigated in cases of meningoencephalitis with unknown etiology [33]. OROV infection is the second most common arboviral infection in Brazil with at least half a million cases [66], and many of these infections occur sporadically [67]. However, this infection has been observed in a small number of studies that were conducted in other regions of the country, excluding the Amazon region [68].

DENV epidemics have often occurred in several Brazilian municipalities, and many cases were not confirmed using laboratory methods, instead using only clinical and epidemiological data. Therefore, developing methods for the differential diagnosis of the DENV and OROV infections is important to prevent the occurrence of false positives and false negatives for dengue or Oropouche fever due to the similarity of their symptoms. Additionally, a potential vector of the OROV in urban areas is the midge Culicoides paraensis, which has wide geographical distribution in the Americas [67]; therefore, additional studies in different regions of Brazil should be conducted to determine the spatial distribution of this vector of the OROV.

YF has two transmission cycles: urban and wild. In the urban cycle, the infected mosquito, such as Aedes aegypti, which is the same vector for dengue, transmits the virus. Because of the difficulty in controlling this mosquito population and the lack of strategies for the mass vaccination of travelers, YF is considered to be a reemerging disease. In severe cases of YF, the mortality rate ranges from $20 \%-50 \%$ [69]. Nunes et 
Moreli et al. Virology Discovery 2013,

http://www.hoajonline.com/journals/pdf/2052-6202-1-1.pdf

doi: $10.7243 / 2052-6202-1-1$

al., evaluated two new methods for the molecular detection of the YFV using the Green qRT-PCR and RT-PCR semi-nested techniques. Both techniques were useful in the early diagnosis of YFV infection and could be used in epidemiological studies of YFV [35].

Moreno et al., performed an entomological study and an eco-epidemiological evaluation of 577 human samples, 108 monkey samples (Callithrix penicillata, Alouatta caraya, Cebus apella and other species) and 3049 midge samples that were collected in the State of São Paulo. Viral isolation, ELISA-IgM RT-PCR, histopathology and immunohistochemistry confirmed the sporadic circulation of the YFV [36]. Deubel et al., isolated the YFV from a fatal case of YF that involved an individual who returned to France after a trip in endemic areas of the Amazon region and who was not vaccinated [69]. Therefore, vaccination against YF in areas that are at risk for travelers and for the populations in these locations is important.

In Brazil, several serological studies have been conducted to elucidate the SLEV $[\mathbf{3 7}, \mathbf{7 0}]$. Antibodies against arbovirus have been observed in $10 \%$ of horses and in $5 \%$ of the human population in the North and Northeast regions [70]. However, the hemagglutination inhibition and ELISA serological tests have demonstrated that cross-reactions between antibodies from different Flaviviruses occur; these reactions are specifically induced by exposure to DENV and in individuals who are vaccinated against YF. In this context, include the ROCV and MAYV, which have caused outbreaks in Manaus, may result in cross-reactivity between several arboviruses [32,46].

Our search for articles in the international scientific literature demonstrated that studies on the differential diagnosis of arboviruses are rare. In addition, a pilot study that originated from countries in South America (i.e., Bolivia, Ecuador, Paraguay and Peru) has garnered attention [71]. This multicenter study was conducted from 2000-2007, and the researchers collected 20880 samples from patients with febrile illness in the acute or convalescent phases using immunofluorescence, RT-PCR and ELISA-IgM. Co-infection or a recent infection with arboviruses was detected in $32.5 \%$ of the samples, among which $26 \%$ were infected with the DENV and $3 \%$ were infected with the VEEV, MAYV, OROV, group C virus or Guaroa virus. However $63.5 \%$ of the samples were collected from patients in the convalescent phase, which may have decreased the sensitivity of the technique.

In this systematic review, we concluded that there are no standardized molecular techniques for the diagnosis of arboviruses, and most of the molecular methods were used in house. However, several authors have focused on developing new tests. Additionally, cross-reactivity and the immune window period are drawbacks in the use of serological methods. However, many patients who had an infection that was suggestive of arbovirus infection were not diagnosed, even when accurate techniques, such as RT-PCR, were used. Therefore, it remains unclear whether these tests resulted in a false negative or whether other etiological agents were present.
A diagnosis that is based only on clinical and epidemiological data would be premature. Therefore, new entomological research and new differential molecular methods should be performed for the possible isolation of these unknown viruses to contribute to the diagnosis of arboviruses.

\section{Competing interests}

The authors declare that they have no competing interests.

\section{Authors' contributions}

MLM and VGC developed and wrote the study protocol. MLM and VGC conducted a search of the scientific literature and analyzed articles according to the selection criteria. MLM and VGC evaluated the data from the studies that were included in the systematic review and wrote the manuscript. Both authors read and approved the final version of the manuscript.

Publication history

Received: 22-Feb-2013 Revised: 24-Mar-2013

Accepted: 26-Mar-2013 Published: 29-Mar-2013

\section{References}

1. Jawetz E, Melnick J, Adelberg E. Microbiologia médica. 22 rd ed. Rio de Janeiro: Mc Graw Hill; 2005: 411-26.

2. Figueiredo LT: Emergent arboviruses in Brazil. Rev Soc Bras Med Trop 2007, 40:224-9. | Article | PubMed

3. WHO. Global alert and response: impact of dengue. Geneva: World Health Organization; 2007. I Article

4. Schneider BS and Higgs S: The enhancement of arbovirus transmission and disease by mosquito saliva is associated with modulation of the host immune response. Trans R Soc Trop Med Hyg 2008, 102:400-8. | Pdf | PubMed Abstract | PubMed Full Text

5. Pedroso ERP, Rocha MOC: Infecções emergentes e reemergentes. Rev Med Minas Gerais 2009, 19: 140-50. I Pdf

6. Romano-Lieber NS, Iversson L: Inquérito soroepidemiológico para pesquisa de infecções por arbovírus em moradores de reserva ecológica. Rev Saúde Pública 2000, 34: 236-42. I Pdf

7. Travassos da Rosa AP, Turell MJ, Watts DM, Powers AM, Vasconcelos PF, Jones JW, Klein TA, Dohm DJ, Shope RE, Degallier N, Popov VL, Russell KL, Weaver SC, Guzman H, Calampa C, Brault AC, Lemon AP and Tesh RB: Trocara virus: a newly recognized Alphavirus (Togaviridae) isolated from mosquitoes in the Amazon Basin. Am J Trop Med Hyg 2001, 64:93-7. | Article | PubMed

8. Carvalho VL, Nunes MR, da Silva EV, Vieira CM, Gomes M, Casseb SM, Rodrigues SG, Nunes-Neto JP, Quaresma JA and Vasconcelos PF: Genetic characterization of orthobunyavirus Melao, strains BE AR633512 and BE AR8033, and experimental infection in golden hamsters (Mesocricetus auratus). J Gen Virol 2009, 90:223-33. | Article | PubMed

9. Figueiredo LT: The Brazilian flaviviruses. Microbes Infect 2000, 2:16439. | Article I PubMed

10. Iversson LB, Silva RA, da Rosa AP and Barros VL: Circulation of eastern equine encephalitis, western equine encephalitis, Ilheus, Maguari and Tacaiuma viruses in equines of the Brazilian Pantanal, South America. Rev Inst Med Trop Sao Paulo 1993, 35:355-9. I Article I PubMed

11. Silva AD and Evangelista Mdo S: Syndromic surveillance: etiologic study of acute febrile illness in dengue suspicious cases with negative serology. Brazil, Federal District, 2008. Rev Inst Med Trop Sao Paulo 2010, 52:237-42. | Article | PubMed

12. Soares CN, Castro MJ, Peralta JM, Freitas MR and Puccioni-Sohler M: Is West Nile virus a potential cause of central nervous system infection in Brazil? Arq Neuropsiquiatr 2010, 68:761-3. | Article | PubMed

13. Blacksell SD, Doust JA, Newton PN, Peacock SJ, Day NP and Dondorp $A M$ : A systematic review and meta-analysis of the diagnostic accuracy of rapid immunochromatographic assays for the detection of dengue virus IgM antibodies during acute infection. Trans $\mathrm{R}$ Soc Trop Med Hyg 2006, 100:775-84. | Article | PubMed

14. Alice FJ: Infecção humana pelo vírus leste de encefalite equina. Bol Inst 
Moreli et al. Virology Discovery 2013,

http://www.hoajonline.com/journals/pdf/2052-6202-1-1.pdf

doi: $10.7243 / 2052-6202-1-1$

Biol 1956, 3: 3-9.

15. Guzman MG and Kouri G: Dengue haemorrhagic fever integral hypothesis: confirming observations, 1987-2007. Trans $R$ Soc Trop Med Hyg 2008, 102:522-3. I Article I PubMed

16. Vasconcelos PFC, Mota K, Straatmann A, Santos-Torres S, Travassos da Rosa APA, Neto JT: Epidemia de dengue em Ipupiara e Prado, Bahia: Inquérito Soro-epidemiológico. Rev Soc Bras Med Trop 2000, 33: 61-67. | Article

17. Nunes MR, Travassos da Rosa AP, Weaver SC, Tesh RB and Vasconcelos PF: Molecular epidemiology of group $C$ viruses (Bunyaviridae, Orthobunyavirus) isolated in the Americas. J Virol 2005, 79:10561-70. | Article | PubMed Abstract | PubMed Full Text

18. Albuquerque IG, Marandino R, Mendonca AP, Nogueira RM, Vasconcelos PF, Guerra LR, Brandao BC, Aguiar GR and Bacco PA: Chikungunya virus infection: report of the first case diagnosed in Rio de Janeiro, Brazil. Rev Soc Bras Med Trop 2012, 45:128-9. | Article | PubMed

19. Rajapakse $S$, Rodrigo $C$ and Rajapakse A: Atypical manifestations of chikungunya infection. Trans R Soc Trop Med Hyg 2010, 104:89-96. | Article | PubMed

20. Townson $\mathrm{H}$ and Nathan MB: Resurgence of chikungunya. Trans $R$ Soc Trop Med Hyg 2008, 102:308-9. | Article I PubMed

21. Vasconcelos PF, Travassos da Rosa ES, Travassos da Rosa JF, de Freitas RB, Degallier N, Rodrigues SG and Travassos da Rosa AP: [Outbreak of classical fever of dengue caused by serotype $\mathbf{2}$ in Araguaiana, Tocantins, Brazil]. Rev Inst Med Trop Sao Paulo 1993, 35:141-8. | Article | PubMed

22. Cruz ACR, Vasconcellos PFC: Arbovírus no Brasil. Biológico São Paulo 2008, 70: 45-46. | Pdf

23. Domingues RB and Teixeira AL: Management of acute viral encephalitis in Brazil. Braz J Infect Dis 2009, 13:433-9. | Article | PubMed

24. Vasconcelos PF, Travassos da Rosa AP, Rodrigues SG, Travassos da Rosa ES, Degallier N and Travassos da Rosa JF: Inadequate management of natural ecosystem in the Brazilian Amazon region results in the emergence and reemergence of arboviruses. Cad Saude Publica 2001, 17 Suppl:155-64. | Article | PubMed

25. de Araujo TP, Rodrigues SG, Costa MI, Vasconcelos PF and da Rosa AP: [Serological diagnosis of dengue and yellow fever infections in suspected cases from Para State, Brazil, 1999]. Rev Soc Bras Med Trop 2002, 35:579-84. | Article | PubMed

26. Vasconcelos PFC, Travassos da Rosa JFS, Travassos da Rosa APA, Dégallier N, Pinheiro FP, Filho GCS: Epidemiologia das encefalites por arbovírus na Amazônia brasileira. Rev Inst Med Trop Sao Paulo 1991, 33: 465-76. | Pdf

27. Kong YY, Thay $\mathrm{CH}$, Tin TC and Devi S: Rapid detection, serotyping and quantitation of dengue viruses by TaqMan real-time one-step RT-PCR. J Virol Methods 2006, 138:123-30. | Article I PubMed

28. Conceicao TM, Da Poian AT and Sorgine MH: A real-time PCR procedure for detection of dengue virus serotypes 1, 2, and 3, and their quantitation in clinical and laboratory samples. J Virol Methods 2010, 163:1-9. | Article | PubMed

29. Sampaio RF, Mancini MC: Estudos de revisão sistemática: uma guia para síntese criteriosa da evidência científica. Rev Bras fisioter 2007, 11: 83-89. I Pdf

30. Linde $\mathrm{K}$ and Willich SN: How objective are systematic reviews? Differences between reviews on complementary medicine. J $R$ Soc Med 2003, 96:17-22. | Article | PubMed Abstract | PubMed Full Text

31. Jadad AR, Cook DJ, Browman GP: A guide to interpreting discordant systemic reviews. Can Med Assoc J 1997, 156: 1411-16. | Pdf

32. Mourão MPG, Bastos MS, Figueiredo RP, Gimaque JBL, Galusso ES, Kramer VM, et al.: Mayaro fever in the city of Manaus, Brazil, 20072008. Vector-Borne Zoonotic Dis 2012, 12: 42-46. I Pdf

33. Bastos Mde S, Figueiredo LT, Naveca FG, Monte RL, Lessa N, Pinto de Figueiredo RM, Gimaque JB, Pivoto Joao G, Ramasawmy R and Mourao MP: Identification of Oropouche Orthobunyavirus in the cerebrospinal fluid of three patients in the Amazonas, Brazil. Am J Trop Med Hyg 2012, 86:732-5. | Article | PubMed

34. Rocco IM, Silveira VR, Maeda AY, Silva SJS, Spenassatto C, Bisordi I, et al.: First isolation of dengue 4 in the State of São Paulo, 2011. Rev Inst Med Trop Sao Paulo 2012, 54: 49-51. | Pdf

35. Nunes MR, Palacios G, Nunes KN, Casseb SM, Martins LC, Quaresma JA, Savji N, Lipkin WI and Vasconcelos PF: Evaluation of two molecular methods for the detection of Yellow fever virus genome. J Virol Methods 2011, 174:29-34. | Article | PubMed

36. Moreno ES, Rocco IM, Bergo ES, Brasil RA, Siciliano MM, Suzuki A, et al: Reemergence of yellow fever: detection of transmission in the State of
São Paulo, Brazil, 2008. Rev Soc Bras Med Trop 2011, 44: 290-96. | Pdf

37. Terzian AC, Mondini A, Bronzoni RV, Drumond BP, Ferro BP, Cabrera EM, Figueiredo LT, Chiaravalloti-Neto F and Nogueira ML: Detection of Saint Louis encephalitis virus in Dengue-suspected cases during a dengue 3 outbreak. Vector Borne Zoonotic Dis 2011, 11:291-300. | Article | PubMed

38. Costa AC, Façanha GP: Sorotipos virais de dengue identificados em crianças de Manaus, Estado do Amazonas, 2008. Rev Soc Bras Med Trop 2011, 44: 249-51. I Pdf

39. Batista WC, Tavares Gda S, Vieira DS, Honda ER, Pereira SS and Tada MS Notification of the first isolation of Cacipacore virus in a human in the State of Rondonia, Brazil. Rev Soc Bras Med Trop 2011, 44:528-30. | Article | PubMed

40. Santana Vdos S, Lavezzo LC, Mondini A, Terzian AC, Bronzoni RV, Rossit AR, Machado RL, Rahal P, Nogueira MC and Nogueira ML: Concurrent Dengue and malaria in the Amazon region. Rev Soc Bras Med Trop 2010, 43:508-11. | Article | PubMed

41. Poloni TR, Oliveira AS, Alfonso HL, Galvao LR, Amarilla AA, Poloni DF, Figueiredo LT and Aquino VH: Detection of dengue virus in saliva and urine by real time RT-PCR. Virol J 2010, 7:22. | Article | PubMed Abstract I PubMed Full Text

42. Vasconcelos HB, Azevedo RS, Casseb SM, Nunes-Neto JP, Chiang JO, Cantuaria PC, Segura MN, Martins LC, Monteiro HA, Rodrigues SG, Nunes $\mathrm{MR}$ and Vasconcelos PF: Oropouche fever epidemic in Northern Brazil: epidemiology and molecular characterization of isolates. J Clin Virol 2009, 44:129-33. | Article | PubMed

43. Calzavara-Silva CE, Gomes AL, Maia RC, Acioli-Santos B, Gil LH and Marques Jr ET: Early molecular markers predictive of dengue hemorrhagic fever. An Acad Bras Cienc 2009, 81:671-7. | Article | PubMed

44. Coimbra TL, Santos RN, Petrella S, Nagasse-Sugahara TK, Castrignano SB and Santos CL: Molecular characterization of two Rocio flavivirus strains isolated during the encephalitis epidemic in Sao Paulo State, Brazil and the development of a one-step RT-PCR assay for diagnosis. Rev Inst Med Trop Sao Paulo 2008, 50:89-94. | Article | PubMed

45. Dos Santos HW, Poloni TR, Souza KP, Muller VD, Tremeschin F, Nali LC, Fantinatti LR, Amarilla AA, Castro HL, Nunes MR, Casseb SM, Vasconcelos PF, Badra SJ, Figueiredo LT and Aquino VH: A simple one-step realtime RT-PCR for diagnosis of dengue virus infection. J Med Virol 2008, 80:1426-33. | Article | PubMed

46. Coimbra TL, Santos CL, Suzuki A, Petrella SM, Bisordi I, Nagamori AH, Marti AT, Santos RN, Fialho DM, Lavigne S, Buzzar MR and Rocco IM: Mayaro virus: imported cases of human infection in Sao Paulo State, Brazil. Rev Inst Med Trop Sao Paulo 2007, 49:221-4. | Article | PubMed

47. Azevedo RS, Nunes MR, Chiang JO, Bensabath G, Vasconcelos HB, Pinto AY, Martins LC, Monteiro HA, Rodrigues SG and Vasconcelos PF: Reemergence of Oropouche fever, northern Brazil. Emerg Infect Dis 2007, 13:912-5. | Article | PubMed Abstract | PubMed Full Text

48. de Morais Bronzoni RV, Baleotti FG, Ribeiro Nogueira RM, Nunes M and Moraes Figueiredo LT: Duplex reverse transcription-PCR followed by nested PCR assays for detection and identification of Brazilian alphaviruses and flaviviruses. J Clin Microbiol 2005, 43:696-702. | Article | PubMed Abstract | PubMed Full Text

49. Rocco IM, Santos CL, Bisordi I, Petrella SM, Pereira LE, Souza RP, Coimbra TL, Bessa TA, Oshiro FM, Lima LB, Cerroni MP, Marti AT, Barbosa VM, Katz $G$ and Suzuki A: St. Louis encephalitis virus: first isolation from a human in Sao Paulo State, Brazil. Rev Inst Med Trop Sao Paulo 2005, 47:281-5. | Article | PubMed

50. Moreli ML, Aquino VH, Cruz AC and Figueiredo LT: Diagnosis of Oropouche virus infection by RT-nested-PCR. J Med Virol 2002, 66:13942. | Article | PubMed

51. Couderc T, Gangneux N, Chretien F, Caro V, Le Luong T, Ducloux B, Tolou $H$, Lecuit $M$ and Grandadam $M$ : Chikungunya virus infection of corneal grafts. J Infect Dis 2012, 206:851-9. I Article I PubMed

52. Dong D, Fu SH, Wang LH, Lv Z, Li TY and Liang GD: Simultaneous detection of three arboviruses using a triplex RT-PCR: enzyme hybridization assay. Virol Sin 2012, 27:179-86. | Article | PubMed

53. He B, Wang HY, Zhang C, Wang M, Qin M, Wang KX and Ma XJ: [Development of a GeXP based multiplex RT-PCR assay for simultaneous detection of eight arboviruses related to encephalitis] Bing Du Xue Bao 2012, 28:57-62. I PubMed

54. Chinikar S, Ghiasi SM, Naddaf S, Piazak N, Moradi M, Razavi MR, Afzali N, Haeri A, Mostafavizadeh K, Ataei B, Khalilifard-Brojeni M, Husseini SM 
Moreli et al. Virology Discovery 2013,

http://www.hoajonline.com/journals/pdf/2052-6202-1-1.pdf

doi: $10.7243 / 2052-6202-1-1$

and Bouloy M: Serological evaluation of Crimean-Congo hemorrhagic fever in humans with high-risk professions living in enzootic regions of Isfahan province of Iran and genetic analysis of circulating strains. Vector Borne Zoonotic Dis 2012, 12:733-8. | Article | PubMed

55. Chinikar S, Javadi A, Ataei B, Shakeri H, Moradi M, Mostafavi E and Ghiasi SM: Detection of West Nile virus genome and specific antibodies in Iranian encephalitis patients. Epidemiol Infect 2012, 140:1525-9. | Article | PubMed

56. Sarkar A, Taraphdar D, Mukhopadhyay SK, Chakrabarti S and Chatterjee $S$ : Serological and molecular diagnosis of Japanese encephalitis reveals an increasing public health problem in the state of West Bengal, India. Trans R Soc Trop Med Hyg 2012, 106:15-9. | Article | PubMed

57. Cavrini F, Della Pepa ME, Gaibani P, Pierro AM, Rossini G, Landini MP and Sambri V: A rapid and specific real-time RT-PCR assay to identify Usutu virus in human plasma, serum, and cerebrospinal fluid. J Clin Virol 2011, 50:221-3. | Article | PubMed

58. Fritel $X$, Rollot O, Gérardin P, Gauzére BA, Bideault J, Lagarde L, et al. Chikungunya virus infection during pregnancy, Réunion, France, 2006. Emerg Infect Dis 2010, 16: 418-25. | Pdf

59. Dussart P, Petit L, Labeau B, Bremand L, Leduc A, Moua D, Matheus S and Baril $\mathrm{L}$ : Evaluation of two new commercial tests for the diagnosis of acute dengue virus infection using NS1 antigen detection in human serum. PLoS Negl Trop Dis 2008, 2:e280. | Article | PubMed Abstract | PubMed Full Text

60. Tan PC, Rajasingam G, Devi S and Omar SZ: Dengue infection in pregnancy: prevalence, vertical transmission, and pregnancy outcome. Obstet Gynecol 2008, 111:1111-7. | Article I PubMed

61. Gozalan A, Esen B, Fitzner J, Tapar FS, Ozkan AP, Georges-Courbot MC Uzun R, Gumuslu F, Akin L and Zeller H: Crimean-Congo haemorrhagic fever cases in Turkey. Scand J Infect Dis 2007, 39:332-6. | Article | PubMed

62. IBGE. cidades: censo demográfico 2010. Geneva: Instituto Brasileiro de Geografia e Estatística Accessed 20 April 2012. | Website

63. Vasconcelos PFC, Rosa TPA, Dégallier N, Rosa TJFS, Pinheiro FP: Clinical and ecoepidemiological situation of human arboviruses in Brazilian Amazonia. J Braz Assoc Advancement of Science 2000, 44:117-124. | Pdf

64. Kuno G: Review of the factors modulating dengue transmission. Epidemiol Rev 1995, 17:321-35. | Article | PubMed

65. Bisordi I, Rocco IM, Suzuki A, Katz G, Silveira VR, Maeda AY, et al.: Evaluation of dengue NS1 antigens detection for diagnosis in public health laboratories, São Paulo State, 2009. Rev Inst Med Trop Sao Paulo 2011, 53: 315-20. | Pdf

66. Pinheiro FP, Travassos da Rosa AP, Travassos da Rosa JF, Ishak R, Freitas RB, Gomes ML, LeDuc JW and Oliva OF: Oropouche virus. I. A review of clinical, epidemiological, and ecological findings. Am J Trop Med Hyg 1981, 30:149-60. | PubMed

67. Bernardes-Terzian AC, de Moraes-Bronzoni RV, Drumond BP, Da SilvaNunes M, da-Silva NS, Urbano-Ferreira M, et al.: Sporadic oropouche virus infection, acre, Brazil. Emerg Infect Dis 2009, 15: 348-350. | Pdf

68. Mourão MP, Bastos MS, Gimaque JB, Mota BR, Souza GS, Grimmer GH, et al.: Oropouche fever outbreak, Manaus, Brazil, 2007-2008. Emerg Infect Dis 2009, 15: 2063-2064. | Pdf

69. Deubel V, Huerre M, Cathomas G, Drouet MT, Wuscher N, Le Guenno $B$ and Widmer AF: Molecular detection and characterization of yellow fever virus in blood and liver specimens of a non-vaccinated fatal human case. J Med Virol 1997, 53:212-7. | Article | PubMed

70. Rodrigues SG, Oliva OP, Araujo FAA, Martins LC, Chiang JO, Henriques $\mathrm{DF}$, et al.: Epidemiology of Saint Louis encephalitis virus in the Brazilian Amazon region and in the State of Mato Grosso do Sul, Brazil: elevated prevalence of antibodies in horses. Rev Pan-Amaz Saude 2010, 1: 81-86. I Pdf

71. Forshey BM, Guevara C, Laguna-Torres VA, Cespedes M, Vargas J, Gianella A, et al.: Arboviral etiologies of acute febrille illnesses in western south America, 2000-2007. PLoS Negl Trop Dis 2010, 4: 1-14. I Pdf

\section{Citation:}

Moreli M L and da Costa V G: A systematic review of molecular diagnostic methods for the detection of arboviruses in clinical specimens in Brazil and the importance of a differential diagnosis. Virology Discovery 2013, 1:1.

http://dx.doi.org/10.7243/2052-6202-1-1 